Journal of Animal and Veterinary Advances 9 (18): 2390-2395, 2010

ISSN: $1680-5593$

(C) Medwell Journals, 2010

\title{
Effects of Different Levels of Probiotic and Prebiotic on Performance and Carcass Characteristics of Broiler Chickens
}

\author{
Marzieh Falaki, Mahmood Shams Shargh, Behroz Dastar and Saeed Zrehdaran \\ Department of Animal Science, \\ Gorgan University of Agriculture Science and Natural Resources, Iran
}

\begin{abstract}
An experiment was conducted to evaluate the effects of different levels of probiotic and prebiotic on growth performance and carcass characteristics of broiler chickens. About 48 sexed male Ross 308 hybrid chickens were used. The birds were assigned six treatment groups in a randomized complete block design. Each treatment allocated to 5 replicates of 16 male broilers and reared for 42 days. The broiler chickens were grown on starter (0-21 days) and grower (22-42 days) diets calculated to meet NRC recommendations and supplemented with different levels of probiotic PRIMALAC $\left(0,900 \mathrm{~g} \mathrm{ton}^{-1}\right)$ and prebiotic FERMACTO $(0,1000$ and $2000 \mathrm{~g} \mathrm{ton}^{-1}$ ). Body weight and feed consumption were determined weekly during the study. Each dietary was fed ad libitum in the whole of experiment. The result of present study showed that the interaction effect between different levels of PRIMALAC and FERMACTO was significant. The highest value of body weight gain was recorded for broilers fed the diet supplemented with mixed of PRIMALAC $\left(900 \mathrm{~g} \mathrm{ton}^{-1}\right)$ and FERMACTO $\left(2000 \mathrm{~g} \mathrm{ton}^{-1}\right)(\mathrm{p}<0.05)$. Lowest feed conversion ratio was belonging to prebiotic $\left(2000 \mathrm{~g} \mathrm{ton}^{-1}\right)$ group and caused more efficient feed intake. The highest significant $(\mathrm{p}<0.05)$ value of carcass and breast were recorded for broilers fed diet supplemented with mixing PRIMALAC and FERMACTO. The percent of carcass, thigh and abdominal fat were not affected by treatments. The results of present study revealed that supplemented diets with mixed of PRIMALAC and FERMACTO (symbiotic) as growth promoters appeared to be superior compare to use alone and improve broiler chickens growth indices.
\end{abstract}

Key words: Primalac, feramcto, performance, carcass traits, broiler, symbiotic

\section{INTRODUCTION}

Feed additive antibiotics have been used as growth promoters for $>50$ years in the feed industry all over the world. Antibiotics induce their effect by stabilizing the intestinal microbial flora thereby preventing proliferation of specific intestinal pathogens (Visek, 1978; Shane, 2005).

Today, the non-prescription use of antibiotics in poultry feeds has been eliminated or severely limited in many countries because of concerns related to development of antibiotic-resistant human pathogenic bacteria and legislative action to limit their use in probable in many others. Since the proposed total ban on subtherapeutic feed antibiotics, products such as prebiotics, organic acids and probiotics are receiving considerable attention in animal nutrition because of their non-residual and non-resistant properties (Mellor, 2000; Gill, 2001; Hertrampf, 2001; Plail, 2006; Kocher, 2005). Probiotics are pure cultures of one or more live microorganisms that exhibit a beneficial effect on the health of the host when they are ingested. Improved epithelial cell integrity, increased immune response, well balanced gut microflora, better utilisation and digestion of diet are also additive beneficial effects of dietary probiotics
(Jin et al., 1998; Wenk, 2000; Panda et al., 2001; Linge, 2005). Gibson and Roberfroid (1995) defined a prebiotic as a non-digestible food ingredient which beneficially affects the host by selectively stimulating the growth of and/or activating the metabolism of one or a limited number of health-promoting bacteria in the intestinal tract, thus improving the host's microbial balance. It has been shown that prebiotics stimulate the growth of endogenous microbial population groups such as bifidobacteria and lactobacilli is specifically stimulated and these bacteria species are perceived as beneficial to animal health.

Probiotics (Vanbelle et al., 1990; Jin et al., 1998) and prebiotics (Shane, 2005; Ferket, 2004) act as growth promoters feed savers, nutritional bio-regulators, immune stimulators and help in improving performance and health. The beneficial effects of the dietary supplementation of prebiotics (Hooge et al., 2003; Bozkurt et al., 2005) and probiotics (Jin et al., 1998; Abdulrahim et al., 1999; Alcicek et al., 2004) on broiler performance are well documented. A prebiotic preparation (MOS) has been shown to interfere with the use of antibiotics in diets of broilers (Waldroup et al., 2003) whereas no benefit has been found relating response of broiler live performance

Corresponding Author: Marzieh Falaki, Second Floor, Hazef Apartment, 26th Alley, Janbaz Street, Zanbazan Boulevard, Gorgan, Iran 
to dietary added MOS in the presence of a probiotic (Hofacre et al., 2003). On the other hand Hooge et al. (2003) reported that MOS alone supported live performance equivalent to antibiotic growth promoters but showed an additive effect when combined with antibiotics.

In simplest definition, symbiotic is a combination of probiotics and prebiotics (Collins and Gibson, 1999). This combination can improve the viability of probiotic microorganisms, since they are able to use prebiotics as a substra for fermentation (Bengmark andBengmark, 2001) Therefore, the objective of the present study was to examine the performance and carcass characteristics of broiler chickens fed an experimental diet containing a prebiotic and a probiotic alone and also the prebiotic in combination with the probiotic to find the most effective synergistic combination of these products.

\section{MATERIALS AND METHODS}

In this study, 480 broiler chickens of the commercial Ross 308 strain in a randomized block design experiment arranged in a $2 \times 3$ factorial schedule ( 2 levels of prebiotic and 3 levels of probiotic) with 6 treatments ( 5 replicates in each treatment 16 birds/replicates) and reared on floor pens for 42 days. Before beginning this study, the dry matter, crude protein, ether extract, crude fiber and ash contents of main feed ingredients were determined (AOAC, 1984) in the laboratory to make sure of presence of sufficient amounts of protein and crude fiber content of the ration.

A basal diet was formulated and considered as control according to recommendation of NRC (1994) for starter (0-21 days) and grower (22-42 days) diets. The composition of the diets and the content of nutrients are shown in Table 1. Five tested diets were formulated by supplemented the basal control diet with FERMACTO (1000 and $2000 \mathrm{~g} \mathrm{ton}^{-1}$ ), PRIMALAC (900 $\left.\mathrm{g} \mathrm{ton}^{-}\right)^{1}$, mixture of FERMACTO (1000 $\left.\mathrm{g} \mathrm{ton}^{-1}\right)+$ PRIMALAC $\left(900 \mathrm{~g} \mathrm{ton}^{-1}\right)$ and mixture of FERMACTO $\left(2000 \mathrm{~g} \mathrm{ton}^{-1}\right)+$ PRIMALAC $\left(900 \mathrm{~g} \mathrm{ton}^{-1}\right)$, respectively.

FERMACTO is a commercial prebiotic of the mannanoligosaccharides family which is obtained by extraction from the outer cell wall of the yeast Saccharomyces cerevisiae. PRIMALAC is a kind of commercial probiotic, consisting of a combined preparation of live microorganisms including Lactobacillus acidophilus, Lactobacillus casei, Enterococcus faecium and Bifidobacterim bifidum (PRIMALAC ${ }^{\circledR}$ Star*labs). During the experiment, water and feed were given to the birds ad libitum. Air temperature and humidity were adjusted according to the ROSS technological procedure for broiler fattening. The ambient temperature in an experimental house was maintained at $32^{\circ} \mathrm{C}$ during the 1 st week and gradually decreased by $3^{\circ} \mathrm{C}$ in the 2 nd and $3 \mathrm{rd}$ week
Table 1: The ingredient and chemical composition of diets administered to broiler chickens

\begin{tabular}{|c|c|c|}
\hline Ingredients & $0-21$ days & $22-42$ days \\
\hline Corn & 56.00 & 61.60 \\
\hline Soybean meal $44 \%$ & 29.00 & 26.00 \\
\hline DCP & 0.85 & 0.85 \\
\hline Corn gluten meal & 3.50 & 0.00 \\
\hline Meat-born Meal & 3.50 & 0.00 \\
\hline Fish meal & 1.50 & 7.00 \\
\hline Sunflower oil & 3.50 & 2.60 \\
\hline Limestone & 0.50 & 0.60 \\
\hline DL-Methionine & 0.35 & 0.05 \\
\hline Vitamin premix ${ }^{1}$ & 0.50 & 0.50 \\
\hline Mineral premix ${ }^{2}$ & 0.50 & 0.50 \\
\hline Salt & 0.30 & 0.30 \\
\hline \multicolumn{3}{|l|}{ Calculated composition } \\
\hline $\mathrm{Cp}$ & 21.90 & 20.60 \\
\hline ME $\left(\mathrm{kcal} \mathrm{kg}^{-1}\right)$ & 3,158 & 3,194 \\
\hline Lysine & 1.18 & 0.99 \\
\hline Methionine and cystine & 0.96 & 1.75 \\
\hline Calcium & 0.90 & 0.89 \\
\hline Phosphorus & 0.44 & 0.42 \\
\hline \multicolumn{3}{|c|}{$\begin{array}{l}{ }^{1} \text { The vitamin premix supplied the following per kilogram of complete feed } \\
\text { vitamin A, } 4,500 \mathrm{IU} \text { (retinyl acetate); cholecalciferol, } 1,000 \mathrm{IU} \text {; vitamin } \mathrm{E} \text {, } \\
25 \mathrm{IU}(\mathrm{dl}-\alpha \text {-tocopheryl acetate); vitamin } \mathrm{B} 12,0.02 \mathrm{mg} \text {; menadione, } 1.5 \mathrm{mg} \text {; } \\
\text { riboflavin, } 3 \mathrm{mg} \text {; thiamine, } 1.5 \mathrm{mg} \text {; pantothenic acid, } 5 \mathrm{mg} \text {; niacin, } 20 \mathrm{mg} \text {; } \\
\text { choline, } 150 \mathrm{mg} \text {; folic acid, } 0.5 \mathrm{mg} \text {; biotin, } 0.5 \mathrm{mg} \text {; pyridoxine, } 2.5 \mathrm{mg} \text {. } \\
{ }^{2} \text { The mineral premix supplied the following per kilogram of complete feed } \\
\text { manganese }\left(\mathrm{MnSO} \cdot \mathrm{H}_{2} \mathrm{O}\right), 60 \mathrm{~g} \text {; zinc }(\mathrm{ZnO}), 40 \mathrm{mg} \text {; iron, }\left(\mathrm{FeSO} 4 \cdot 7 \mathrm{H}_{2} \mathrm{O} \text { ), }\right. \\
80 \mathrm{mg} \text {; copper }\left(\mathrm{CuSO}{ }^{\circ} \cdot 5 \mathrm{H}_{2} \mathrm{O}\right), 8 \mathrm{mg} \text {; selenium }\left(\mathrm{Na}_{2} \mathrm{SeO}_{3}\right), 0.2 \mathrm{mg} \text {; iodine } \\
(\text { Iodized } \mathrm{NaCl}), 0.8 \mathrm{mg} \text {; cobalt }\left(\mathrm{CoCl}_{2}\right), 0.4 \mathrm{mg}\end{array}$} \\
\hline
\end{tabular}

and exposed to natural environmental conditions thereafter. Chicks were vaccinated against Infectious Bursal Disease, New Castle Diseases HB1 and Lasota at days 14,21 and 28 , respectively, via the drinking water. During the 42 days experimental period, the growth performance of broiler chickens was evaluated by recording body weight, feed intake, feed conversion ratio. Weighing of the feed and chickens were made on a weekly basis. At the end of the experiment (at 42 day), 30 chickens birds of similar body weight to the group average were selected from each treatment group (1 chicken per replicate), weighted and killed by severing of the bronchial vein. After evisceration, hot carcasses were weighted immediately to determine the hot carcass yield. The weights of the Carcass, Breast, Thigh and abdominal fat were recorded individually. The weights of these selected internal parts were expressed as a percentage of preslaughter live weight of the broilers. Also, at the end of training period, feed intake, weight gain and feed conversion ratio were calculated.

Statistical analysis: All data were analyzed using the one-way ANOVA procedure of SAS (1998) for analysis of variance. Significant differences among treatments were identified at $5 \%$ level by Duncan (1955) multiple range tests.

\section{RESULTS AND DISCUSSION}

Supplemental effects of prebiotic, probiotic and Interaction effect between different levels of prebiotic and 
J. Anim.Vet. Adv., 9 (18): 2390-2395, 2010

Table 2: Body weight, feed intake and feed conversion ratio of broilers receiving diet supplemented with different levels of probiotic and prebiotic

\begin{tabular}{|c|c|c|c|c|c|c|c|c|c|}
\hline \multirow[b]{2}{*}{ Treatments } & \multicolumn{3}{|c|}{$0-21$ days } & \multicolumn{3}{|l|}{$22-42$ days } & \multicolumn{3}{|l|}{$0-42$ days } \\
\hline & BW (g) & FI (g) & $\mathrm{FC}$ & BW (g) & FI (g) & $\mathrm{FC}$ & BW (g) & FI (g) & $\mathrm{FC}$ \\
\hline \multicolumn{10}{|l|}{ Prebiotic } \\
\hline $\mathrm{P}_{0}$ & $566.29^{a}$ & $1003.84^{a}$ & $1.785^{\mathrm{a}}$ & $1635.58^{b}$ & $3337.84^{a}$ & $2.051^{\mathrm{a}}$ & $2194.86^{b}$ & $4334.67^{\mathrm{a}}$ & $1.9790^{\mathrm{a}}$ \\
\hline $\mathrm{P} 1$ & $563.58^{\mathrm{a}}$ & $986.55^{\mathrm{a}}$ & $1.784^{\mathrm{a}}$ & $1635.29^{b}$ & $3310.78^{a}$ & $2.034^{a}$ & $2191.87^{b}$ & $4290.33^{\mathrm{a}}$ & $1.9640^{\mathrm{a}}$ \\
\hline $\mathrm{P}_{2}$ & $597.19^{a}$ & $1000.75^{\mathrm{a}}$ & $1.689^{\mathrm{a}}$ & $1728.88^{\mathrm{a}}$ & $3322.06^{\mathrm{a}}$ & $1.926^{\mathrm{a}}$ & $2319.07^{\mathrm{a}}$ & $4315.81^{\mathrm{a}}$ & $1.8650^{b}$ \\
\hline SEM & 11.36 & 21.57 & 0.039 & 27.44 & 41.48 & 0.048 & 30.86 & 50.3 & 0.0310 \\
\hline $\begin{array}{l}\text { p-value } \\
\text { probiotic }\end{array}$ & 0.0933 & 0.833 & 0.159 & 0.0394 & 0.898 & 0.169 & 0.0046 & 0.733 & 0.0320 \\
\hline 1 & $519.34^{b}$ & $948.26^{b}$ & $1.841^{b}$ & $1614.54^{b}$ & $3165.74^{b}$ & $1.961^{\mathrm{a}}$ & $2126.87^{b}$ & $4107^{\circ}$ & $1.9350^{\mathrm{a}}$ \\
\hline 2 & $632.04^{\mathrm{a}}$ & $1045.83^{\mathrm{a}}$ & $1.665^{\mathrm{a}}$ & $1718.63^{\mathrm{a}}$ & $3481.37^{\mathrm{a}}$ & $2.045^{\mathrm{a}}$ & $2343.67^{\mathrm{a}}$ & $4520.2^{\mathrm{a}}$ & $1.9360^{\mathrm{a}}$ \\
\hline SEM & 9.26 & 17.58 & 0.032 & 22.35 & 33.81 & 0.039 & 32.89 & 52.19 & 0.0240 \\
\hline$p$-value & 0.0001 & 0.001 & 0.001 & 0.004 & 0.0001 & 0.199 & 0.0001 & 0.0001 & 0.8533 \\
\hline \multicolumn{10}{|l|}{ Pro*pre } \\
\hline \multicolumn{10}{|l|}{1} \\
\hline$P_{0}$ & $525.08^{b}$ & $952.36^{b}$ & $1.824^{\mathrm{ab}}$ & $1649.08^{b c}$ & $3211.9^{b}$ & $1.952^{\mathrm{ab}}$ & $2167.16^{\mathrm{dc}}$ & $4157.26^{b}$ & $1.9210^{\mathrm{abc}}$ \\
\hline $\mathrm{P} 1$ & $495.98^{b}$ & $954.41^{b}$ & $1.944^{\mathrm{a}}$ & $1564.36^{\mathrm{d}}$ & $3161.75^{b}$ & $2.027^{\mathrm{ab}}$ & $2053.34^{d}$ & $4109.16^{b}$ & $2.0060^{\mathrm{a}}$ \\
\hline $\mathrm{P} 2$ & $536.96^{b}$ & $938.02^{b}$ & $1.756^{b c}$ & $1630.17^{\mathrm{bc}}$ & $3123.58^{b}$ & $1.921^{\mathrm{b}}$ & $2160.13^{\mathrm{dc}}$ & $4054.6^{b}$ & $1.8810^{b c}$ \\
\hline \multicolumn{10}{|c|}{ 100. } \\
\hline $\mathrm{P}_{0}$ & $607.49^{a}$ & $1055.32^{\mathrm{a}}$ & $1.747^{\mathrm{bc}}$ & $1523.07^{\mathrm{bc}}$ & $3463.78^{\mathrm{a}}$ & $2.15^{\mathrm{a}}$ & $2222.57^{\mathrm{bc}}$ & $4512.09^{a}$ & $2.0370^{\mathrm{a}}$ \\
\hline P1 & $631.19^{a}$ & $1018.68^{\mathrm{ab}}$ & $1.627^{\circ}$ & $1706.22^{b}$ & $3459.81^{a}$ & $2.04^{a b}$ & $2330.41^{b}$ & $4471.5^{\mathrm{a}}$ & $1.9230^{\mathrm{abc}}$ \\
\hline $\mathrm{P} 2$ & $657.43^{\mathrm{a}}$ & $1063.49^{\mathrm{a}}$ & $1.623^{c}$ & $1827.6^{\mathrm{a}}$ & $3520.53^{\mathrm{a}}$ & $1.931^{\mathrm{ab}}$ & $2478.02^{\mathrm{a}}$ & $4577.02^{\mathrm{a}}$ & $1.8500^{c}$ \\
\hline SEM & 16.02 & 30.42 & 0.1009 & 38.67 & 58.49 & 0.048 & 39.87 & 70.72 & 0.0450 \\
\hline $\mathrm{p}$-value & 0.262 & 0.6042 & 0.2016 & 0.024 & 0.4636 & 0.313 & 0.0062 & 0.3377 & 0.1029 \\
\hline
\end{tabular}

probiotic on performance of broiler chickens are shown in Table 2. Symbiotic group (PRIMALAC+FERMACTO) showed higher feed intake in each period and all over of the trial. In the starter period, prebiotic (FERMACTO) had lower feed intake and there wasn't any significant difference between different levels of FERMACTO $(p>0.05)$. Interaction effect between different levels of prebiotic and probiotic had no additive benefit at 0-21 days. The results of this experiment clearly showed that the supplemented diet with prebiotic and probiotic stimulated the growth of broilers during the grower and whole of experimental period. In all periods of the experiment, probiotic group showed higher feed consumption whereas different levels of FERMACTO hadn't significant difference ( $p>0.05)$. The results of current trial showed that the substitution of the control by probiotic $\left(900 \mathrm{~g} \mathrm{ton}^{-1}\right)$ resulted in significantly higher body weight gain at different periods of the experiment. The Probiotic (PRIMALAC), prebiotic (FERMACTO $2000 \mathrm{~g} \mathrm{ton}^{-1}$ ) and Symbiotic (PRIMALAC+FERMACTO) had best performance on weight gain of chicks.

In the grower period, the differences of weight gain for FERMACTO (2000 $\mathrm{g} \mathrm{ton}^{-1}$ ) group was significantly higher than compare to other levels of FERMACTO $(\mathrm{p}<0.05)$. In the birds under treatment of primal in the starter of experiment the feed conversion ratio improved significantly when compared to control group $(\mathrm{p}<0.05$ ). The dietary supplemented with different levels of FERMACTO had no effect on weight gain and feed conversion ratio in the starter period of current study. During the entire experimental period, the dietary supplemented with FERMACTO (2000 $\mathrm{g} \mathrm{ton}^{-1}$ ) were increased the weight of birds to 128 and $125 \mathrm{~g}$, respectively compared to control diet. The weight gain was increased for birds fed PRIMALAC by $10.2 \%$ compared to control diet. The interaction effect between different levels of PRIMALAC and FERMACTO was significant. The highest value of body weight gain was recorded for broilers fed the diet supplemented with mixture of PRIMALAC $\left(900 \mathrm{~g} \mathrm{ton}^{-1}\right)$ and FERMACTO (1000 and $2000 \mathrm{~g} \mathrm{ton}^{-1}$ ). Also, from 1-42 days, supplemented diet with FERMACTO had no effect on the feed consumption of the birds. In the birds under treatments of FERMACTO (2000 $\mathrm{g} \mathrm{ton}^{-1}$ ), the feed conversion ratio improved significantly when compared to control group $(\mathrm{p}<0.05)$.

Carcass composition: The effect of experimental treatments on the composition of the bird carcasses are shown in Table 3. The Slaughter weight of the birds under FERMACTO (2000 $\left.\mathrm{g} \mathrm{ton}^{-1}\right)$ treatment was significantly higher as compared with the other levels of FERMACTO $(p<0.05)$. The Slaughter weight and Carcass weight of the birds obtaining a ration containing symbiotic $\left(900 \mathrm{~g} \mathrm{ton}^{-1}\right.$ PRIMALAC+2000 $\mathrm{g} \mathrm{ton}^{-1}$ FERMACTO) showed a higher mean as compared with the control treatment $(\mathrm{p}<0.05)$. Also in the birds under treatments of PRIMALAC $\left(900 \mathrm{~g} \mathrm{ton}^{-1}\right)$ the Slaughter weight, Carcass weight and 
Table 3: The effect of treatment on slaughter weight, carcass yield and abdominal fat of male broilers receiving diet supplemented with different levels of probiotic and prebiotic

\begin{tabular}{|c|c|c|c|c|c|c|}
\hline Treatments & Weight (g) & Carcass weight (g) & Carcass yield (\%) & Breast (\%) & Thigh (\%) & Abdominal fat $(\%)$ \\
\hline \multicolumn{7}{|l|}{ Prebiotic } \\
\hline P0 & $2177^{b}$ & $1594.5^{b}$ & $73.140^{\mathrm{a}}$ & $27.320^{b}$ & $31.25^{\mathrm{a}}$ & $2.940^{a}$ \\
\hline P1 & $2232^{b}$ & $1586.38^{b}$ & $71.840^{a}$ & $29.550^{\mathrm{a}}$ & $31.22^{\mathrm{a}}$ & $2.520^{a}$ \\
\hline P2 & $2374.5^{\mathrm{a}}$ & $1763.25^{\mathrm{a}}$ & $74.230^{\mathrm{a}}$ & $29.690^{b}$ & $30.82^{\mathrm{a}}$ & $2.500^{\mathrm{a}}$ \\
\hline SEM & 26.31 & 31.2 & 1.520 & 0.600 & 0.84 & 0.160 \\
\hline $\mathrm{p}$-value & 0.0002 & 0.009 & 0.315 & 0.021 & 0.4995 & 0.254 \\
\hline \multicolumn{7}{|l|}{ Probiotic } \\
\hline 1 & $2177^{b}$ & $1592.83^{b}$ & $72.330^{\mathrm{a}}$ & $28.090^{b}$ & $30.69^{a}$ & $2.520^{\mathrm{a}}$ \\
\hline 2 & $2345.33^{a}$ & $1703.25^{a}$ & $73.180^{a}$ & $29.630^{a}$ & $30.07^{a}$ & $2.800^{a}$ \\
\hline SEM & 24.3 & 28.32 & 1.220 & 0.490 & 0.68 & 0.160 \\
\hline $\mathrm{p}$-value & 0.0001 & 0.006 & 0.648 & 0.042 & 0.151 & 0.247 \\
\hline \multicolumn{7}{|l|}{ Pro*pre } \\
\hline \multicolumn{7}{|l|}{1} \\
\hline P0 & $2209.5^{\text {dc }}$ & $1630.7^{\mathrm{bc}}$ & $73.520^{\mathrm{a}}$ & $26.900^{\circ}$ & $31.7^{\mathrm{a}}$ & $2.500^{\mathrm{ba}}$ \\
\hline P1 & $2092.4^{\mathrm{d}}$ & $1510.7^{c}$ & $72.120^{a}$ & $28.900^{\mathrm{abc}}$ & $31^{\mathrm{a}}$ & $2.100^{b}$ \\
\hline $\mathrm{P} 2$ & $2229.5^{c}$ & $1637^{\mathrm{bc}}$ & $73.800^{a}$ & $28.300^{0 \mathrm{bc}}$ & $31.3^{\mathrm{a}}$ & $2.800^{b}$ \\
\hline \multicolumn{7}{|l|}{2} \\
\hline P0 & $2144.5^{\mathrm{dc}}$ & $1558.2^{\mathrm{bc}}$ & $72.400^{a}$ & $27.700^{b c}$ & $30.4^{a}$ & $3.200^{a}$ \\
\hline P1 & $2372^{b}$ & $1662^{b}$ & $70.180^{a}$ & $30.100^{\mathrm{ab}}$ & $31.2^{\mathrm{a}}$ & $2.800^{\mathrm{ab}}$ \\
\hline P2 & $2519.5^{\mathrm{a}}$ & $1889.5^{\mathrm{a}}$ & $74.700^{a}$ & $31.000^{2}$ & $30.1^{\mathrm{a}}$ & $2.200^{b}$ \\
\hline SEM & 41.8 & 44.2 & 2.250 & 0.860 & 0.6 & 0.280 \\
\hline $\mathrm{p}$-value & 0.0002 & 0.0046 & 0.712 & 0.458 & 0.233 & 0.071 \\
\hline
\end{tabular}

percent breast improved significantly when compared to control group $(\mathrm{p}<0.05)$. Supplemented diet with different levels of FERMACTO and PRIMALAC treatments had no effect on the efficiency of the thigh, carcass yield and percent abdominal fat of the birds. In general, the positive effect of experimental additives tested on performance is in agreement with the results reported by several researchers. Kermanshahi and Rostami (2006) and Nayebpor et al. (2007) reported that prebiotics and probiotics can improve the weight of birds. Moreover, adding probiotic and synbiotic to the ration has been effective in improving the feed conversion ratio (Zulkifli et al., 2000; Cavit, 2004). In contrast, Ignacio (1995) reported that the use of prebiotics in the ration of broiler chickens reduces the feed conversion ratio. Yalcinkayal et al. (2008) reported that using the probiotic and prebiotic in broiler ration had no significant effects on body weight gain and feed ration after experiment period of 42 days. In agreement with the result of this study, there are numerous reports showing that the use of such additives has no effect on the feed consumption (Yalcinkayal et al., 2008; Willis et al., 2007).

Variance among reports of researchers could be related to differences in management and environmental conditions that be exist in various experiments. It's suggested that under benefit management and/or environmental conditions, the effect of such feed additives may be worthless. The results of current experiment indicate that broilers fed the FERMACTO plus PRIMALAC were more efficient at converting feed to body mass during the rearing period. To stimulate the growth of beneficial bacteria in the gut using a prebiotic and probiotic combination was more effective than the supplemented with prebiotic and probiotic alone. In general, improvements in feed efficiency were attributed to an encouraged growth of the beneficial micro flora in the GIT induced by dietary supplementation of prebiotric and probiotic. In addition to an antimicrobial activity, a significantly increased intestinal amylase enzyme activity was determined in a recent study when adding $L$. acidophulus and a mixture of Lactobacilli to the diets (Jin et al., 1997). Furthermore, (Yeo and Kim, 1997) reported that the improvement in feed efficiency of birds receiving probiotic supplemented diets could be due to decreased urease activity in the GI tract of the broiler chicks. Present findings shown that consumption of PRIMALAC-FERMACTO mixture had a positive effect on the body weight gain. The reason may be ascribed to the synergism of PRIMALAC and FERMACTO. Following the concurrent action of prebiotics fermentation by lactic acid bacteria in the GI tract and production of some acids by this group of bacteria, the $\mathrm{pH}$ of the GI tract is further reduced (Fuller, 1989). Reduction in $\mathrm{pH}$ is effective in controlling the population of pathogenic bacteria. During the infections due to pathogenic bacteria, lymphocytes crowd up to kill them and after inflammation, the thickness of the muscular layer increases (Gunal et al., 2006). It seems that in the study, due to the synergism between PRIMALAC and FERMACTO followed by absorption of nutrients by the GI system, the birds under symbiotic treatment had a better feed conversion ratio. 
Use of PRIMALAC in diet improved body weight at slaughter. The growth-promoting effects of probiotics are dependent on the specific probiotics, the application level of probiotics, the age of birds as well as the delivery method (i.e., via water and/or feed). Kabir et al. (2004) have reported that adding $2 \mathrm{~g}$ probiotic per each liter of water consumed by broiler chickens would increase the efficiency in their thigh and breast as compared with the control treatment that confirm the positive effect of PRIMALAC on breast yield in this study. In the Ammerman et al. (1989) study adding 0.375\% oligofructose to the birds ration on day 47 , decreased the percent of abdominal fat. However, present findings on carcasse composition were in contrast to those of Plail (2006) and Willis et al. (2007). As pointed out before, these differences between reported results could be related to management and environmental conditions.

In this study, it seems that the use of mixture of PRIMALAC and FERMACTO by improving the uptake of nutrients and increase in nitrogen stability can improve the carcass quality. Also, by observing a reduction in the fat level of birds fed by prebiotic, it is suggested that this product can interfere in the accessibility to fat for formation of fat tissue in the birds. The effects of feed additives used in this study were associated with growth stimulation, enhanced nutrient digestion and absorption, though this enhancement was not converted to carcass yield. Similar observations were reported by Panda et al. (2001) and Alcicek et al. (2004) for probiotics and by Bozkurt et al., 2005; Waldroup et al., 2003) for prebiotics. Dietary treatments had no significant effect on abdominal fat pad accumulation in the present study. Similar results were observed by researchers who studied supplementation of prebiotics (Waldroup et al., 2003; Bozkurt et al., 2005) and probiotics (Denli et al., 2003; Alcicek et al., 2004) to broiler diets.

The results of some studies shown that growth stimulating probiotic, increase the growth of broiler chickens by an increase in the uptake of nutrients (especially fatty acids and glucose), fixation of nitrogen and reduction in excretion of fat in the feces and microbial urea (Willis et al., 2007). The prebiotic reduces the number of bacteria, toxins and their secondary products in the GI tract (Gunal et al., 2006).

\section{CONCLUSION}

The results of present study showed that supplementation of broiler diets with a prebiotic and a probiotic significantly increased the body weight gain with slightly improved feed conversion ratios, compared with the unsupplemented control. Combining strategies of prebiotic with probiotic proved additive benefit in growth performance and feed conversion ratio than that of individual use of these additives. In this case, it was shown that a prebiotic preparation is an ideal match with a probiotic preparation to optimize digestion, thus to convert feed to body mass more effectively.

\section{REFERENCES}

AOAC., 1984. Official Methods of Analysis. 14th Edn., The William Byrd Press Inc., Richmond, Verginia, USA.

Abdulrahim, S.M., M.S.Y. Haddadin, N.H.M. Odetallah and R.K. Robinson, 1999. Effect of Lactobacillus acidophilus and zinc bacitracin as dietary additives for broiler chickens. Br. Poult. Sci., 40: 91-94.

Alcicek, A., M. Bozkurt and M. Cabuk, 2004. The effects of a mixture of herbal essential oil, an organic acid or a probiotic on broiler performance. South Afr. J. Anim. Sci., 34: 217-222.

Ammerman, E., C. Quarles and P.V. Twining, 1989. Evaluation of fructooligosaccharides on performance and carcass yield of male broilers. Poult. Sci., 68: 167-167.

Bengmark, S. and S. Bengmark, 2001. Pre-pro-and synbiotics. Curr. Opin. Clin. Nutr. Metab. Care, 4: $571-579$.

Bozkurt, M., K. Kucukyilmaz, A.U. Catli and M. Cinar, 2005. Growth performance and carcass yield of broiler chickens given antibiotic, mannan oligosaccharide and dextran oligosaccharide supplemented diets. Proceedings of the 21st Annual Symposium on Nutritional Biotechnology in the Feed and Food Industries, May 22-25, Lexington, Kentucky, USA., pp: 69-69.

Cavit, A., 2004. Effect of dietary probiotic supplementation on growth performance in the rock partridge (Alectoris graeca). Turk. J. Vet. Anim. Sci., 28: 887-891.

Collins, M.D. and G.R. Gibson, 1999. Probiotics, prebiotics and symbiotics: Approaches for modulating the microbial ecology of the gut. Am. J. Clin. Nutr., 69: 1052S-1057S.

Denli, M., F. Okan and K. Celik, 2003. Effect of dietary probiotic, organic acid and antibiotic supplementation to diets on broiler performance and carcass yield. Pak. J. Nutr., 2: 89-91.

Duncan, D.B., 1955. Multiple range and multiple F-tests. Biometrics, 11: 1-42.

Ferket, P.R., 2004. Alternatives to antibiotics in poultry production: Responses, practical experience and recommendations. Proceedings of Alltech's 20th Annual Symposium, (AAS'04), Nottingham, UK., pp: 56-67. 
Fuller, R., 1989. Probiotics in man and animals. A review. J. Applied Bacterol, 66: 365-378.

Gibson, G.R. and M.B. Roberfroid, 1995. Dietary modulation of the human colonic microbiota: Introducing the concept of prebiotics. J. Nutr., 125: 1401-1412.

Gill, C., 2001. Safe and sustainable feed ingredients. Feed Int., 22: 40-45.

Gunal, M., G. Yayli, O. Kaya, N. Karahan and O. Sulak, 2006. The effects of antibiotic growth promoter, probiotic or organic acid supplementation on performance, intestinal microflora and tissue of broiler. Int. J. Poult. Sci., 5: 149-155.

Hertrampf, J.W., 2001. Alternative antibacterial performance promoters. Poult. Int., 40: 50-52.

Hofacre, C.L., T. Beacorn, S. Collet and G. Mathis, 2003. Using competitive exclusion, mannanoligosaccharide and other intestinal products to control necrotic enteritis. J. Applied Poult. Res., 12: $60-64$.

Hooge, D.M., M.D. Sims, A.E. Sefton, A. Connolly and P. Spring, 2003. Effect of dietary mannan oligosaccharide, with or without bacitracin or virginiamycin, on live performance of broiler chickens at relatively high stocking density on new litter. J. Applied Poult. Res., 12: 461-467.

Ignacio, E.D., 1995. Evaluation of the effect of yeast culture on the growth performance of broiler chick. Poult. Sci., 74: 196-196.

Jin, L.Z., Y.W. Ho, N. Abdullah and S. Jalaludin, 1997. Probiotics in poultry: Modes of action. Worlds Poul. Sci. J., 53: 351-368.

Jin, L.Z., Y.W. Ho, N. Abdullah and S. Jalaludin, 1998. Growth performance, intestinal microbial populations and serum cholesterol of broilers fed diets containing Lactobacillus cultures. Poult. Sci., 77: 1259-1265.

Kabir, S.M.L., M.B. Rahman, M.M. Rahman and S.U. Ahmed, 2004. The dynamics of-probiotics on growth performance and immune response in broilers. Int. J. Poult. Sci., 3: 361-364.

Kermanshahi, $H$. and $H$. Rostami, 2006. Influence of supplemental dried whey on broiler performance and cecal flora. Int. J. Poult. Sci., 5: 538-543.

Kocher, A., 2005. AGP alternatives-part IV. Poultry production without AGPs-Challenges and solutions. World Poult., 21: 32-33.

Linge, P., 2005. The use of probiotics and yeast derivatives in India. World Poultry, 21: 12-15.

Mellor, S., 2000. Nutraceuticals-alternatives to antibiotics. World Poult., 16: 30-33.

NRC, 1994. Nutrient Requirements of Poultry. 9th Edn., National Academy Press, Washington, DC., USA., ISBN-13: 978-0-309-04892-7.
Nayebpor, M., P. Farhomand and A. Hashemi, 2007. Effect of different levels of direct fed microbial (Primalac) on the growth performance and humoral immune response in broiler chickens. J. Anim. Adv., 6: 1308-1313.

Panda, A.K., M.R. Reddy and N.K. Praharaj, 2001. Dietary supplementation of probiotic on growth, serum cholesterol and gut microflora of broilers. Indian. J. Anim. Sci., 71: 488-490.

Plail, R., 2006. The innovative power of probiotics. Poult. Int., 45: 34-36.

SAS, 1998. SAS/STAT User's Guide. SAS Institute Inc., Cary. NC.

Shane, S., 2005. Antibiotic alternatives in turkey production. World Poult., 19: 14-15.

Vanbelle, M., E. Teller and M. Focant, 1990. Probiotics in animal nutrition: A review. Arch. Anim. Nutr., 40: $543-567$.

Visek, W.J., 1978. The mode of growth promotion by antibiotics. J. Anim. Sci., 46: 1447-1469.

Waldroup, P.W., C.A. Fritts and F. Yan, 2003. Utilization of Bio-Mos ${ }^{\circledR}$ mannan oligosaccharide and Bioplex ${ }^{\circledR}$ copper in broiler diets. Int. J. Poult. Sci., 2: 44-52.

Wenk, C., 2000. Recent advances in animal feed additives such as metabolic modifiers, antimicrobial agents, probiotics, enzymes and highly available minerals. Rev. Asian-Aust. J. Anim. Sci., 13: 86-95.

Willis, W.L., O.S. Isikhuemhen and S.A. Ibrahim, 2007. Performance assessment of broiler chickens given mushroom extract alone or in combination with probiotics. Poult. Sci., 86: 1856-1860.

Yalcinkayal, H., T. Gungori, M. Bafialani and E. Erdem, 2008. Mannan oligosaccharides (MOS) from Saccharomyces cerevisiae in broilers: Effects on performance and blood biochemistry. Turk. J. Vet. Anim. Sci., 32: 43-48.

Yeo, J. and K. Kim, 1997. Effect of feeding diets containing an antibiotic, a probiotic, or yucca extract on growth and intestinal urease activity in broiler chicks. Poult. Sci., 76: 381-385.

Zulkifli, I., N. Abdullah, N.M. Azrin and Y.W. Ho, 2000. Growth performance and immune response of two commercial broiler strains fed diets containing Lactobacillus cultures and oxytetracycline under heat stress conditions. Br. Poult. Sci., 41: 593-597. 